\title{
Validation of the Indonesian version of the graded chronic pain scale 2.0 in pain- related temporomandibular disorders
}

Ira Tanti, Vivi Vidya Waty Wira, Yenni Pragustine, Laura Susanti Himawan, Nina Ariani

Check for updates

pISSN: 0853-1773 • elSSN: 2252-8083 https://doi.org/10.13181/mji.oa.191790 Med J Indones. 2020;29:42-6

Received: January 23, 2017

Accepted: June 23, 2019

Authors' affiliations:

Department of Prosthodontics, Faculty of Dentistry, Universitas Indonesia, Jakarta, Indonesia

Corresponding author:

Ira Tanti

Department of Prosthodontics, Faculty of Dentistry, Universitas Indonesia, Jalan Salemba Raya No. 4, Central Jakarta 10430, DKI Jakarta, Indonesia

Tel/Fax: +62-21-3151216

E-mail: iratanti@ymail.com

\begin{abstract}
BACKGROUND Pain associated with oral problems is one of the most frequent chronic pain of temporomandibular disorders (TMDs). This study was conducted to analyze the psychometric properties of the Indonesian version of the graded chronic pain scale 2.0 (GCPS-ID) in Indonesian patients with TMDs.
\end{abstract}

METHODS The English version of the GCPS version 2.0 was translated and backtranslated according to international guidelines. This study conducted from June to December 2016 at the Dental Hospital, Faculty of Dentistry, Universitas Indonesia, and the participants were 202 TMDs patients who had never undergone temporomandibular joint surgery or suffered facial pain for more than 6 months. The evaluation of the GCPS-ID included the internal consistency test, test-retest reliability, and construct validity tests.

RESULTS The GCPS-ID had a high internal consistency (Cronbach's alpha = 0.896). The intraclass correlation coefficient of the pain intensity and the disability score were 0.789 and 0.706 , respectively. The convergent validity demonstrated a moderately positive correlation between the GCPS-ID and the Indonesian version of oral health impact profile for TMD for pain $(r=0.595$; $p<0.001)$ and disability $(r=0.488 ; p<0.001)$. The discriminant validity between GCPSID and the subjective patient's quality of life revealed a weak positive correlation $(r=$ $0.195 ; p=0.191)$.

CONCLUSIONS GCPS-ID is a reliable and valid assessment tool for evaluating TMD pain in Indonesia.

KEYWORDS chronic pain, Indonesia, temporomandibular disorders
One of the most common types of pain associated with oral problems is the chronic pain of temporomandibular disorders (TMDs). TMDs are a collective term encompassing a broad clinical spectrum of joint and muscle problems in the orofacial area. These disorders are characterized by jaw pain, joint sound, limited jaw function, headache, neck pain, shoulder pain, and tinnitus. ${ }^{1}$ It has been reported that TMDs affects approximately $5-12 \%$ of the population and are the second most common musculoskeletal problems, causing pain and disability, after chronic low back pain.
Early detection and prompt management of pain are essential in the treatment of patients with TMDs. Forssell et $\mathrm{al}^{2}$ reported that approximately $30 \%$ of TMD cases were detected at a later onset after having developed into chronic pain, which hampered the daily activities, psychosocial functioning, and quality of life of the patients. Physicians and dentists might contribute to the late diagnosis of TMD pain by not properly evaluating the pain during the course of patient care. Pain with high intensity and disability signal can increase the risk for poor prognosis of TMD pain. That 
being said, having a valid and reliable pain assessment instrument at hand would probably improve their opportunities for recognizing and treating TMD pain in a timely manner. ${ }^{1-4}$

One of the most widely known instruments to assess pain is the graded chronic pain scale (GCPS) 2.0, an eight-item self-report questionnaire designed to measure two constructs, i.e., chronic pain intensity and the level of disability as a result of the pain. The "chronic pain intensity" construct is theoretically represented by four questions addressing the number of days with pain, current pain intensity, the highest pain intensity within the past 30 days, and the average pain intensity within the past 30 days, the latter three of which are measured using a 1-10 scale. The "level of disability" construct is represented by the other 4 questions covering the extent to which the pain disturbs the patient's daily activities, social functions, and work performance within the past 30 days..$^{5-8}$

Although the GCPS 2.0 has been used in several studies in different countries, there has been no documented evidence indicating its application among Indonesian patients. In this study, we aimed at producing an Indonesian version of the GCPS 2.0 (GCPS-ID) that could be applicable among patients with TMDs in Indonesia. For this purpose, we used the cross-cultural adaptation technique. ${ }^{9}$ As pain is currently considered as a vital sign, addressing it correctly in a timely manner should be the priority of all clinicians in managing their patients. The GCPS-ID that we developed could be a useful aid for Indonesian physicians to quantify the patients' subjective feeling of pain and make better treatment plan thereafter.

\section{METHODS}

A cross-sectional study was conducted using a consecutive sample of 202 patients with TMDs who were being treated in June until December 2016 at the Dental Hospital, Faculty of Dentistry, Universitas Indonesia. The sample size was calculated using the formula for validity test, with 92 subjects as minimum sample. ${ }^{10,11}$

The inclusion criteria were patients $\geq 17$ years old; not have systemic diseases such as systemic rheumatic, neurological/neuropathic, or autoimmune diseases; not taking certain medications such as muscle relaxants, steroids, and antidepressants; not undergoing radiation therapy for head and neck malignancies; no history of mental disorders; and had never undergone temporomandibular joint surgery or suffered facial pain for more than 6 months.

Patients who were unwilling to participate in the study and unable to communicate were excluded. The diagnosis of TMD in the eligible patients used the temporomandibular disorders diagnostic index (TMD-DI) questionnaire. Patients with a TMD-DI score >3 were classified as having a TMD. ${ }^{12}$ This study was approved by the Research Ethics Review Committee of the Dental Hospital, Faculty of Dentistry, Universitas Indonesia (No: 8/Ethical Approval/FKGUI/I/2016).

The cross-cultural adaptation technique involved five steps. The first step was translating the GCPS 2.0 from English to Indonesian after obtaining permission from the GCPS inventor, Michael Von Korff (Figure 1). The first step was translation done separately by two translators who were not from medical field. The second step was synthesis of the two translated documents and it was done by the translators and researchers to get one translated questionnaire. The third step was back-translation into English by the two previous translators. The fourth step was discussion by three prosthodontists who were experts in TMD to check the content validity of the translated the GCPS-ID. This first draft was tested in 10 subjects with TMDs. After each subject completed the questionnaire, he/she was interviewed to explore his/her thought about the meaning of each question and response. Next, some semantic changes were made based on the subjects' feedback. The second draft of GCPS-ID was created and examined for its reliability and validity. ${ }^{9}$

GCPS 2.0 questionnaire had eight questions consisted of pain intensity and disability. Pain intensity was calculated as a mean of answer number 2 till 4 (current pain, worst pain, average pain) and it was multiplied by 10 . Disability points was measured by adding the points from disability days and interference score. Interference score was calculated as a mean of answer number 6-8 (daily, social, and work activities) and it was multiplied by 10 , then it was converted to points. Interference score of 0-29 was converted to o point, 30-49 to 1 point, 50-69 to 2 points, and $\geq 70$ to 3 points. Disability days were asked in question number 5 and converted into points. Disability days of 0-6 was converted to o point, 7-14 to 1 point, $15-30$ to 2 points, and $\geq 31$ to 3 points. The chronic pain was then graded as: grade 0 if the pain intensity was 0 ; grade I if the pain 
Figure 1. The Indonesian translation of the graded chronic pain scale version 2.0 questionnaire. The English version is available at http://www.rdc-tmdinternational.org.
1. Berapa harikah dalam 6 bulan terakhir Anda mengalami nyeri di bagian wajah? hari

2. Menurut Anda, berapakah tingkatan nyeri wajah Anda SAAT INI? Gunakan skala mulai dari 0-10, di mana 0 adalah "sama sekali tidak nyeri" dan 10 adalah "sakit luar biasa".

Sama sekali tidak nyeri Sakit luar biasa

$\begin{array}{lllllllllll}0 & 1 & 2 & 3 & 4 & 5 & 6 & 7 & 8 & 9 & 10\end{array}$

3. Dalam rentang waktu 30 HARI TERAKHIR berapakah, berapakah tingkatan nyeri wajah Anda yang TERBURUK? Gunakan skala mulai dari 0-10, di mana 0 adalah "sama sekali tidak nyeri" dan 10 adalah "sakit luar biasa".

Sama sekali tidak nyeri $34 \quad$ Sakit luar biasa

4. Dalam rentang waktu 30 HARI TERAKHIR, RATA-RATA, berapakah tingkatan nyeri wajah Anda? Gunakan skala mulai dari 0-10, di mana 0 adalah "sama sekali tidak nyeri" dan 10 adalah "sakit luar biasa". (Yang berarti, nyeri yang biasanya dirasakan saat Anda sedang merasa sakit).

Sama sekali tidak nyeri Sakit luar biasa

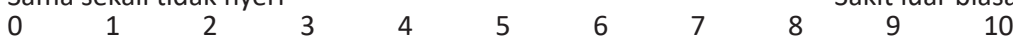

5. Dalam rentang waktu 30 HARI TERAKHIR, berapa harikah nyeri wajah yang Anda rasakan mencegah Anda melaksanakan KEGIATAN RUTIN Anda seperti bekerja, bersekolah atau melakukan pekerjaan rumah? (setiap hari $=30$ hari) hari

6. Dalam rentang waktu 30 HARI TERAKHIR, bagaimana nyeri wajah yang terjadi telah mengganggu KEGIATAN HARIAN Anda? Gunakan skala mulai dari 0-10, di mana 0 adalah "tidak ada gangguan" dan 10 adalah "tidak dapat beraktifitas".

Sama sekali tidak nyeri Sakit luar biasa $\begin{array}{rrrrrrrrrrr}0 & 1 & 2 & 3 & 4 & 5 & 6 & 7 & 8 & 9 & 10\end{array}$

7. Dalam rentang waktu 30 HARI TERAKHIR, bagaimana nyeri wajah yan terjadi mengganggu KEGIATAN REKREASI, SOSIAL DAN KELUARGA Anda? gunakan skala 0-10, di mana 0 adalah "tidak ada gangguan" dan 10 adalah "tidak dapat beraktifitas".

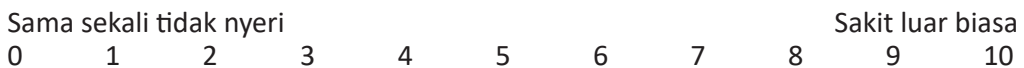

8. Dalam rentang waktu 30 HARI TERAKHIR, bagaimana nyeri wajah yang terjadi mengganggu KEMAMPUAN BEKERJA Anda, termasuk pekerjaan rumah tangga? gunakan skala 0-10, di mana 0 adalah "tidak ada gangguan" dan 10 adalah "tidak dapat beraktifitas".

Sama sekali tidak nyeri Sakit luar biasa

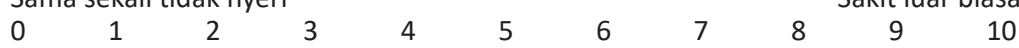

intensity was $<50$ with disability points was $<3$; grade II if the pain intensity was $\geq 50$; grade III if the disability points was 3-4; grade IV if the disability points was 5-6.8,13

Reliability was measured by determining the internal consistency and the test-retest reliability of the GCPS-ID using data obtained from 45 participants who completed the GCPS-ID again after a 2-week interval. An intraclass correlation coefficient (ICC) of $>0.80$ was considered to indicate "very good" agreement between the test and retest results. The test-retest reliability was determined using the ICC, and the internal consistency was evaluated by calculating Cronbach's alpha, wherein a Cronbach's alpha of $>0.70$ was considered as acceptable. ${ }^{14,15}$

Validity was assessed as convergent and discriminant validity. Convergent validity was determined by investigating the correlation between the GCPS-ID and the Indonesian version of oral health impact profile for TMD (OHIP-TMD-ID). The convergent validity test was conducted to determine the measures that are supposed to be measuring the same construct and indicating that they are related. Conversely, in the discriminant validity test, we intended to determine the measures that are not supposed to be related are in fact unrelated, by measuring the correlation between the GCPS-ID and the subjective assessment of the quality of life using a question, "How would you rate your quality of life (good, moderate, poor)?" The Spearman's rank correlation and Gamma correlation test coefficient $(r)$ value were used to indicate the degree of correlation. $r=0$ means no correlation; $r<0.3$ means weak correlation; $r \geq 0.3$ and $<0.7$ means 
moderate correlation; $r \geq 0.7$ means strong correlation; and $r=1$ means perfect correlation. ${ }^{16}$ Data analysis was done using the SPSS software, version 20 (IBM) for Windows.

\section{RESULTS}

A total of 202 patients with TMDs were recruited from the Dental School in Universitas Indonesia. The minimum age was 17 years, and the maximum was 65 years. Female sex was reported $80 \%$ of the total subjects in which $78 \%$ were aged $17-25$ years.

The synthesized version of the eight items was considered to be equivalent, with no difficulties. The word clarity of GCPS-ID was evaluated by the expert and a slight adaptation of the content of the GCPS-ID has been made. The word "pain" had several Indonesian translations. The discussion was primarily based on which word would be most appropriate. No difficulty was encountered during any part of the translation and adaptation. Ten participants in the pretest had no difficulty to response the items of the GCPS-ID. All the GCPS-ID questionnaires were completed.

The test-retest reliability was calculated for 45 participants who repeated the test after 2 weeks. The ICC of the pain intensity was $0.789(\mathrm{Cl} 95 \%=$ $0.624-0.882)$ and the disability score was $0.706(\mathrm{Cl}$ $95 \%=0.474-0.836)$. Both of them were considered as good agreement. The reliability test of the GCPSID questionnaire resulted in a Cronbach's alpha value of 0.896 , which indicated that the items in the questionnaire had a high internal consistency.

The convergent validity test demonstrated a moderate correlation between the GCPS-ID and the

Table 1. The discriminant correlation between GCPS-ID and subjective quality of life

\begin{tabular}{lcccccc}
\hline & \multicolumn{9}{c}{ Subjective quality of life } & & \multirow{2}{*}{$r^{*}$} & $p$ \\
\cline { 3 - 5 } & & Good & Moderate & Poor & & \\
\hline \multirow{4}{*}{ GCPS-ID } & I & 99 & 13 & 0 & 0.195 & 0.191 \\
grade & II & 12 & 4 & 0 & & \\
& III & 3 & 5 & 1 & & \\
& IV & 0 & 0 & 1 & & \\
Total & & 149 & 50 & 3 & & \\
\hline
\end{tabular}

GCPS-ID=the Indonesian version of the graded chronic pain scale 2.0 *Gamma correlation test
OHIP-TMD-ID ( $\mathrm{N}=202)$. Pain intensity of the GCPS-ID was correlated with higher physical pain score of the OHIP-TMD-ID ( $r=0.595 ; p<0.001)$, meanwhile disability points of GCPS-ID was also correlated with the higher disability score of the OHIP-TMD-ID ( $r=0.488$; $p<0.001)$.

The discriminant validity test was performed to compare the GCPS-ID and the subjective quality of life assessment (Table 1). The severity of chronic pain showed no alteration in subjective quality of life patients.

\section{DISCUSSION}

GCPS-ID was successfully adapted from GCPS 2.0 to Indonesian language to evaluate pain intensity and pain-related disability with good internal consistency, reliability, and validity in Indonesian patients with TMDs. The guidelines for cross-cultural adaptation in health sciences were used as a reference to validate the scale. Cross-cultural adaptation is to find out mistranslation and to prevent the translated words may be understood but irrelevant in Indonesian. ${ }^{9}$ Content validity of the GCPS-ID was satisfactory. A slight adaptation was made on the word "pain". Therefore, this indicate that the GCPS-ID was successfully crossculturally adapted to the Indonesian version.

A Cronbach's alpha of 0.896 indicated that the internal consistency of the questionnaire was acceptable. It was similar to the Spanish version of $0.87 .{ }^{17}$ It was difficult to determine the test-retest reliability since the shorter interval would help the subject from recalling the previous answers, meanwhile longer interval would make clinical changes. Although there is no best interval specified, a period of 1-2 weeks is generally considered to be adequate. A close interval may improve the correlation between the test and retest results. ${ }^{16-18}$ In this study, the interval was 2 weeks.

In an earlier study, González et al ${ }^{19}$ reported an ICC value of 0.96 for the GCPS. In the present study, the ICC values were 0.789 for the pain intensity and 0.706 for the disability. These means that the GCPS-ID is a reliable tool to assess the pain intensity and disabilityassociated pain in Indonesian patients with TMDs. This may be caused by different study populations in this study which included only patients with TMDs, meanwhile González et al ${ }^{18}$ included patients with and without TMDs. There may also be different aspects 
of sociocultural in Indonesia compared to Western countries in terms of information exposure, culture, and privacy.

Testing the validity using convergent validity test is important to determine how close the new instrument correlates to the earlier instrument (OHIP TMD-ID questionnaire in physical pain and physical disability). There were positive correlation between the severity of chronic pain and the quality of life in terms of physical pain and physical disabilities. Tjakkes et $\mathrm{al}^{5}$ also demonstrated a significant correlation between duration of pain with the subscale for physical functioning and mandibular impairment. ${ }^{4,19}$

The discriminant validity was also evaluated by correlating it with subjective quality of life, but no correlation was found. Zheng et $\mathrm{al}^{19}$ reported that pain relatively did not have big impact on the patients' daily lives. They found that the patients were able to control pain through their coping strategies and they had already adapted to the pain as part of their lives. ${ }^{19}$

The differences between the GCPS-ID and the other version were the sample size and the study populations. The Spanish version involved 75 patients with low back pain, whereas this Indonesian version evaluated 202 patients with TMDs. Moreover, von Korff et al evaluated 2,371 patients with low back pain, headache, and TMDs. ${ }^{20}$

There are some limitations of this study. First, we did not analyze the causes of chronic pain since the TMD pain were complex and multifactorial. Next, the pathogenesis of TMDs was not analyzed since it was not clear enough. During data collection, patients sometimes failed to recall how many times they have experienced pain and this may had affected the results. This study is important for early detection and management of pain to reduce the burden of the patients. The GCPS-ID could be a simple, reliable, and valid assessment tool for measuring pain for TMD in Indonesian people.

\section{Conflict of Interest}

The authors affirm no conflict of interest in this study.

\section{Acknowledgment}

The authors would like to express our gratitude to Michael Von Korff which has allowed the use of the graded chronic pain scale 2.0.

\section{Funding Sources}

The study is supported by Dana Hibah PITTA Universitas Indonesia.

\section{REFERENCES}

1. Okeson JP. Management of temporomandibular disorders and occlusion. 7th ed. St. Louis: Elsevier Mosby; 2013. p. 4-7, 36, 108, 133, 171.

2. Forssell H, Kauko T, Kotiranta U, Suvinen T. Predictors for future clinically significant pain in patients with temporomandibular disorder: a prospective cohort study. Eur J Pain. 2017;21(1):188-97.

3. Schiffman E, Ohrbach R, Truelove E, Look J, Anderson G, Goulet JP, et al. Diagnostic criteria for temporomandibular disorder (DC/TMD) for clinical and research applications: recommendations of the international RDC/TMD consortium network* and orofacial pain special interest group ${ }^{\dagger}$. J Oral Facial Pain Headache. 2014;28(1):6-27.

4. Moeliono M. Physical modalities in pain management. Paper presented at: PIT IDI pain symposium; 2008 Nov 1; Bandung, Indonesia. Indonesian.

5. Tjakkes G, Reinders J, Tenvergert E, Stegenga B. TMD pain: the effect on health related quality of life and the influence of pain duration. Health Qual Life Outcomes. 2010;8:46.

6. Van der Meulen MJ, John MT, Naeije M, Lobbezoo F. Developing abbreviated OHIP versions for use with TMD patients. J Oral Rehabil. 2012;39(1):18-27.

7. Manfredini D, Ahlberg J, Winocur E, Guarda-Nardini L, Lobbezoo F. Correlation of RDC/TMD axis I diagnoses and axis II pain-related disability. A multicenter study. Clin Oral Investig. 2011;15(5):749-56.

8. Von Korff M. Graded chronic pain scale version 2.0 [Internet]. [cited 2016 Jun 10, updated 2013 Dec 5]. Available from: https://ubwp.buffalo.edu/rdc-tmdinternational/tmdassessmentdiagnosis/dc-tmd/.

9. Beaton DE, Bombardier C, Guillemin F, Ferraz MB. Guidelines for the process of cross-cultural adaptation of self-report measures. Spine. 2000;25(24):3186-91.

10. Dahlan MS. Sample size and method of taking samples in medical and health research. 3rd ed. Jakarta: Salemba Medika; 2010. p. 111-7. Indonesian.

11. Tanti I, Himawan LS, Kusdhany L, Bachtiar A, Ismail RI. Validation of stress screening questionnaire in temporomandibular disorders patient. J Int Dent Med Res. 2016;9(Special Issue):272-6.

12. Himawan LS, Kusdhany L, Ismail I. Diagnostic index for temporomandibula disorders in Indonesia. Thai J Oral Maxillofac Surg. 2006;20(2):104-110.

13. Ohrbach R, KnibbeW. Diagnostic criteria for temporomandibular disorders: scoring manual for self-report instruments. [Internet]. [cited 2018 Dec 10, updated 2016 May 29]. Available from: https://ubwp.buffalo.edu/rdc-tmdinternational/.

14. Nunnally JC, Bernstein IH. Psychometric theory. New York: McGraw-Hill; 2005.

15. DeVellis RF. Scale development: theory and applications. Newbury Park: Sage; 2011.

16. Ferrer-Peña R, Gil-Martínez A, Pardo-Montero J, Jiménez-Penick, Gallego-Izquierdo, La Touche R. Adaptation and validation of the Spanish version of the graded chronic pain scale. Reumatol Clin. 2016;12(3):130-8.

17. Miettinen $\mathrm{O}$, Lahti S, Sipilä K. Psychosocial aspects of temporomandibular disorders and oral health-related qualityof-life. Acta Odontol Scand. 2012;70(4):331-6.

18. González Y, Miranda-Rivera Y, Espinosa I. Crosscultural adaptation of research diagnostic criteria for temporomandibular disorders (RDC/TMD). Rev Fac Odontol Univ Antioq. 2013;25(1):11-25.

19. Zheng J, Wong M, Lam C. Key factors associated with oral health-related quality of life (OHRQOL) in Hong Kong Chinese adults with orofacial pain. J Dent. 2011;39(8):564-71.

20. Von Korff M, Ormel J, Keefe FJ, Dworkin SF. Grading the severity of chronic pain. Pain. 1992;50:133-49. 